\title{
THE FUTURE OF MONETARY INTEGRATION IN THE EEU
}
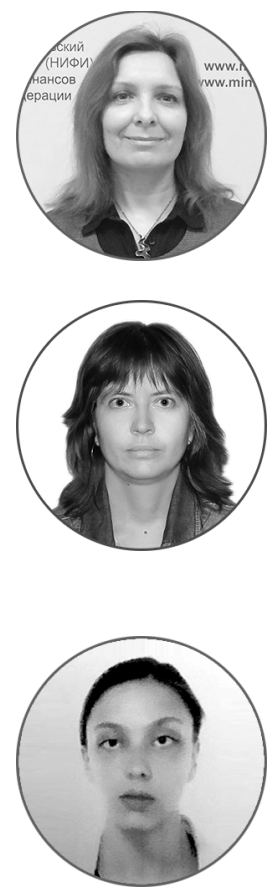

\section{Article history:}

Received 1 July 2017

Received in revised form 5 December 2017

Accepted 12 December 2017

Translated 22 August 2018

Available online 28 September 2018

JEL classification: E41, E44, F10, F15

Keywords: exchange rate, currency internationalization, trade invoicing, inflation, monetary policy

\section{Kristina V. SHVANDAR}

Financial Research Institute of Ministry of Finance of Russian Federation (FRI), Moscow, Russian Federation shvandar@nifi.ru

ORCID: https://orcid.org/0000-0001-9946-5681

\section{Anastasiya A. ANISIMOVA}

Financial Research Institute of Ministry of Finance of Russian Federation (FRI), Moscow, Russian Federation aanisimova@nifi.ru ORCID: https://orcid.org/0000-0001-6421-8349

\section{Corresponding author}

\section{Irina I. YAKOVLEVA}

Russian Presidential Academy of National Economy and Public Administration (RANEPA), Moscow, Russian Federation irinaiyakovleva@gmail.com ORCID: https://orcid.org/000-0003-0871-8706

\begin{abstract}
Importance Almost all regions experience active processes of economic integration. As a result, national currencies become more usable for international payments. The trends are observed in the Eurasian Economic Union (EEU), with the Russian ruble obviously dominating the other currencies.

Objectives We identify factors that streamline invoicing processes denominated in national currencies throughout the EEU.

Methods We refer to China to analyze the main reasons for using the home currency in international payments, scrutinize the payment mechanism under stringent constraints on the currency laws. Summarizing and analyzing the renminbi internationalization practices, we conclude on the most important factors that intensified payments in national currencies throughout the EEU.

Results The article names key factors making the countries use their home currencies to close trade deals. We also express our opinion on the future of payments denominated in the Russian rubles and EEU currencies.

Conclusions and Relevance National currencies are used for international invoicing purposes due to profound trade ties with partners and accessibility of finance, stability of the exchange rate and intention to reduce the USD dominance. The Russian ruble becomes more influential throughout the EEU due to a special status of Russia in the EEU. Russia is the main supplier of energy resources, having the most developed financial market and being free from any legislative barriers to making payments in national currencies throughout the EEU countries.
\end{abstract}

(c) Publishing house FINANCE and CREDIT, 2017

The editor-in-charge of this article was Irina M. Vechkanova

Authorized translation by Irina M. Vechkanova

Please cite this article as: Shvandar K.V., Anisimova A.A., Yakovleva I.I. The Future of Monetary Integration in the EEU. Digest Finance, 2018, vol. 23, iss. 3, pp. 297-307. https://doi.org/10.24891/df.23.3.297 
The Russian ruble demonstrably tends to become a regional currency for a growing number of reasons seen for the recent years. This statement can be illustrated with the active use of the Russian ruble in the EEU cross-border payments. Thus, there should be effective measures to maintain the high volume of payments in the Russian ruble throughout the geography of integration processes.

The U.S. dollar still circulates for the EEU payments, remaining rather competitive. In 2014-2015, the devaluation of the Russian ruble undermined mutual trade and seriously affected the confidence of Russia's Eurasian partners in the integration project. However, they voice absolutely controversial views on strengths and weaknesses of the Eurasian Economic Space and Customs Union, including payment issues.

Home currencies are no longer considered as a means of payment outside the EEU (Ukraine, Turkey, Egypt), though such plans were quite realistic. This is a testimony of risks which should not be overlooked in relationships with the EEU partners. Hence, it is worth the effort to maintain the existing position and status of the Russian ruble in payments throughout the Eurasian integration space and give a new impetus to the project.

China demonstrates impressive results in promoting its national currency worldwide [1, 2]. Before 2009, when there were no bans to use the yuan for foreign trade deals between the mainland and Hong Kong, trade in goods and services was almost null. In 2015, payments were made on a quarterly basis as much as CNY 1.5-2 trillion (equivalent to USD $300-400$ billion).

According to the Society for Worldwide Interbank Financial Telecommunications - SWIFT, in 2015, the yuan went fifth among the most circulating international currencies (Fig. 1). However, the yuan internationalization contradicts some key ideas of the factors that contribute to its involvement into international payments.

${ }^{\dagger}$ For the source article, please refer to: Швандар К.В., Анисимова А.А., Яковлева И.И. Перспективы валютной интеграции стран ЕАЭС. Финансовая аналитика: проблемы и решения. 2018. Т. 11 № 2. C. 205-222. URL: https://doi.org/10.24891/fa.11.2.205
The Chinese monetary legislation is not liberal. As a matter of fact, the yuan held in mainland China and offshore areas cannot be considered as one and the same currency, circulating concurrently and independently and being subject to different jurisdictions. The home yuan can be used only for the export and import of goods, while the offshore yuan can also serve for the same purpose, but including other current and capital transactions.

Nonresidents and residents were gradually permitted to invest in the Chinese or foreign financial markets respectively, but the pace of the process was still slower than the increasing use of the yuan for foreign trade deals, but rather keeping the pace of the latter, if needed. Furthermore, the legislative and regulatory framework became even more stringent to support the weakening yuan.

Currently, China Foreign Exchange Trading System (CFETS, Chinamoney) features sections of 23 currency pairs including the yuan. This implies the currencies should have market quotations, which traders may consider as reference values. However, they are not very representative.

For example, in February 2017, the CNY/USD pair accounted for 96.2 percent of total deals closed. Percentage of trade based on CNY/EUR and CNY/JPY exceeded 1 percent. 13 currencies were lower than 1 percent, with seven of them falling below 0.1 percent (CNY/RUB pair is 0.03 percent). The rest seven currencies were not involved in any transaction.

In China the existing system of international payments and invoicing is run through correspondence banking and Chinese offshore clearing banks. In 2015, China began implementing the China Interbank Payment System - CIPS, which settles the yuan-based payments among clearing banks and the China National Advanced Payment System - CNAPS. The system is a product of nonliberal currency laws. Single-currency settlements are handled within the CIPS [3].

It is worth mentioning how the People's Bank of China created the China Domestic Foreign Currency Payment System - CDFCPS for real-time interbank 
settlement in foreign currency, such as EUR, JPY, GBP, CHF, USD, CAD and HKD [4]. As part of this Ysystem, the People's Bank of China receives payment orders for transfer of loans, carries the netting of each currency and circulates orders for transfer of funds among direct participants' accounts to all settlement agents'.

This example does not serve as an immediate applied solution to arrange multicurrency settlements among two or several countries since it constitutes a domestic payment mechanism (the mainland part, to be more exact). However, CDFCPS does not process settlements relating to currency conversion transactions.

It is important to mention that multicurrency settlements were arranged between CDFCPS in mainland China and real-time gross settlement systems (RTGS) in Hong Kong through Clearing House Automated Transfer Systems - CHATS. To do so, the People's Bank of China appointed settlement institutions ${ }^{2}$ to be in charge of four currencies (EUR, GBP, USD and HKD). Settlement institutions partner with agent banks in Hong Kong, which are mainly their subsidiaries. Settlement banks and agent banks can exchange orders and settle accounts with other banks through local RTGS (CDFCPS and CHATS), with the information being transferred via interbank channels and RTGS means (Fig. 2).

The above example illustrates how an international multicurrency system operates and makes real-time settlements, but we should remember its purpose. It is expected to process money transfers denominated in freely circulating foreign currencies, which have no relation to the region, but are actively involved in domestic and bilateral payments. It is generally intended to circumvent the unbundling of payments through correspondents in the countries of the currencies, cut costs and information risks. This justifies costs for creating and organizing the system and its operation.

\footnotetext{
${ }^{1}$ Settlements are made by direct participants, which have their own accounts with settlement agents of the system, and indirect participants, which act through direct participants. Both of them serve payments of their customers.

${ }^{2}$ Bank of China (USD), Industrial and Commercial Bank of China (EUR), Shanghai Pudong Development Bank (GBP) and China Construction Bank (HKD).
}

Experts in the Asian Development Bank cite four reasons explaining a rapid growth in international yuan-based payments, notwithstanding the above unfavorable legislative factors $[5,6]$ :

- considerable increase in the circulation of commodities between China and neighboring Southeast Asia in 2010;

- stable position of the yuan exchange rate against the U.S. dollar due to the inflexible foreign exchange regime in China. However, China pursued to gradually strengthen the yuan, thus making the yuan-based revenue more substantial for foreign suppliers of goods. Doing so, China actually paid for imported goods with its national currency;

- setting up a network of currency swaps (yuanbased liquidity charged upon the national currency of the second party to the agreement) between the People's Bank of China and central banks of respective counties willing to do so due to the unstable situation in financial markets after 2008;

- return of Hong Kong to China (1997), thus letting China take control over the financial center with well established international ties and infrastructure.

Considering the effects of the above factors, China laid the fundamental basis for the yuan internationalization project and seized its available opportunities to integrate into foreign financial systems by setting up a network of banks tuning the payment and settlement infrastructure. This becomes possible since substantial financial resources are concentrated in the national banking system and the government controls too-big-to-fail banks.

In early 2015, the pool of the yuan-denominated liquidity held outside mainland China was estimated as much as CNY 2 trillion, being equivalent to about USD 400 billion).

Relying upon the yuan internationalization practice, we can make some meaningful conclusions on key factors influencing settlements in national currencies of the EEU countries. 
1. The primary importance of the extent of trade ties with partners and accessibility of funding, while legislative and infrastructure aspects are secondary;

2. Stability of the foreign exchange rate against the reference currency (freely floating) is more important than the existence of exchange rates that are directly pegged to trade partners' currencies, while the growing currency is welcome by counterparts as a means of payment for supplies;

3. The situation in the international monetary system during and after the 2008-2012 crises contributed to promotion of regional currencies as a means of international payments.

The strategy for the development of mutual settlements in the EEU raises the question of priority. Shall the EEU countries opt for the Russian rubles when trading with Russia? Shall they take efforts expanding the area of using the partners' national currencies for payments? The first scenario seems more auspicious, while the second one is a matter of a more distant future.

In the EEU the Russian ruble is actively used for trade invoicing between Russia and the partners and money transfers from Russia. However, few mutual settlements among the Eurasian partners of Russia are denominated in the Russian ruble. Their own national currencies are almost out of use (Fig. 3 and 4). As mutual trade volumes and reciprocal transfers are not substantial, except for the economic cooperation between Kazakhstan and Kyrgyzstan, the situation is unlikely to change considerably. The EEU countries have yet to make a long way towards an integrated payment space in retail markets of goods and services and financial markets ${ }^{3}$ $[7,8]$.

\footnotetext{
${ }^{3}$ Avdeeva D.B. [The development of payment and settlement relations in the national currencies between the member States of the EAEC, CIS and BRICS, and the fulfillment of mutual financial operations]. Mezhdunarodnoe sotrudnichestvo evraziiskikh gosudarstv: politika, ekonomika, pravo = International Cooperation of the Eurasian States: Policy, Economics, Law, 2015, no. 4. URL: https://cyberleninka.ru/article/v/razvitie-platezhno-raschetnyhotnosheniy-v-natsionalnyh-valyutahmezhdu-gosudarstvami-chlenamieaes-sng-briks-i-ispolnenie-vzaimnyh (In Russ.); Sotnikov A.E. [Integration of national payment card systems in the EEU]. PLAS: Platezhi. Sistemy. Kartochki = PLUS Journal, 2015, no. 2. (In Russ.)
}

Therefore, costs for the ambitious project of multicurrency payment infrastructure can hardly be justified economically.

Low liquidity of markets of the EEU currencies conversion is another hindrance, not to mention macroeconomic conditions and policy which are not conductive to stable exchange rates. In other words, high foreign exchange risk impedes the initiative ${ }^{4}$ [9$11]$.

The EEU countries hold multiple meetings discussing the currency integration and concerted currency policy so as to put an end to their ambivalence between stable prices or stable exchange rate $[12$, 13].

After the Central Bank of Russia embarked on inflation targeting through the ruble free float regime, Kazakhstan followed the practice and subsequently became incapable of steering the tenge within the former currency policy. Belarus also allowed its national currency to be flexible, configuring its monetary policy so as to control a growth in money supply. In both cases, the revision of the monetary policy led to the devaluation and increased volatility of national currency exchange rates against the Russian ruble and the U.S. dollar. The Kyrgyzstani som and Armenian dram have been growing more volatile since 2013.

There is little likelihood that central banks will reassume the exchange rate stability course in the mid run due to, inter alia, the existing situation in the global hydrocarbon market and limited liquidity denominated in freely circulating currencies. Lowering the inflation (stable prices) will remain the priority, being regarded as a key driver of the favorable investment climate and departure from the overwhelming use of the U.S. dollar.

However, it does not seem realistic to set the uniform benchmark inflation rate within the EEU as offered by the Eurasian Economic Commission in order to stabilize the exchange rates of the national currencies due to a number of reasons.

\footnotetext{
${ }^{4}$ Matveev M.M. [Problems of currency integration in the conditions of the Euroasian Economic Union]. Ekonomika i menedzhment innovatsionnykh tekhnologii = Economics and Innovations Management, 2015, no. 9. URL: http://ekonomika.snauka.ru/2015/09/7916 (In Russ.)
} 
The five economies still preserve their fundamental and structural distinctions and vulnerability to asymmetric shocks, which may fuel the volatility of exchange rates of certain currencies. Furthermore, remaining on the focus of economic regulators, the exchange rate of each national currency cannot but be subject to their decisions and actions guided by economic reasons and motivation.

The five economies would hardly have agreed upon the rate to which the inflation should have been reduced. It is mainly due to the fact that they have no elaborated and generally accepted framework for mathematical modeling, which would underlie such a coordination effort. Central banks of the EEU countries apply different mechanisms to attain operational goals of their monetary policies, with their efficiency also being unequal.

What seems even more difficult is to coordinate the monetary and fiscal policy as part of the multinational union. However, it is a crucial requirement to make inflation targeting efficient, especially considering the concerted monetary policy of several countries.

It is difficult to capture benefits of inflation targeting as a framework for the monetary policy in transition economies. As seen from the case of Armenia, this has not made prices less volatile for a ten year time, but curbed the economic growth. The central bank of Armenia has reoriented its attention from the stability of prices to the stability of exchange rates, i.e. the policy followed the opposite trend as compared with other EEU countries.

It is reasonable to remember that the EEU countries will be configuring their monetary policy in the mid run so as to stabilize internal inflationary processes but still pursuing their own goals of lowering the inflation and leaving a considerable room for mutual exchange rates and USD exchange rate to fluctuate.

More stable (predictable) exchange rates can hardly ever urge the EEU countries to settle their accounts with national currencies. Right be those experts who believe that the existing extent to which the Russian ruble is used for payments between Russia and the EEU partners and its further increase will give impetus to the performance of the EEU Treaty, including its provisions on concerted macroeconomic and currency policy.

Hence, the long-term currency integration program should focus on the use of the Russian ruble as a unit of account, with legislative and infrastructure aspects being of secondary significance.

Under the existing currency laws, the EEU countries got to use the Russian ruble more actively through interbank correspondence and over-the-counter exchange of currencies, though quotations are not very representative so far.

Considering all the above statements, we suppose that the situation greatly depends on measures for increasing the potential for mutual trade within the EEU. In this respect, different options could be practicable, ranging from dedicated proactive solutions to adaptive tactics.

It is essential for the Eurasian integration to expand the circulation of commodities among the EEU countries (Fig. 5), diversify its composition, remain competitive and expand their share, if possible. Another important step is to minimize withdrawals from the general trade regime and cut non-tariff barriers.

Mutual trade and investment should be financially supported.

As for weaknesses of inflation targeting, the EEU countries will not manage to tackle a steadily high interest rate, even if they attain their interim goals and ensure the appropriate price growth rate. If the economy needs some transformation, high interest rates will prevent it from abolishing outdated and lagging constructs and trigger unproductive effects due to the inflation of costs.

As their monetary policy is primarily aimed to reduce inflation (ensure the stability of prices), large developing economies often create concurrent systems to sustain the economic growth with affordable loans. For example, Brazil, India and South Korea.

As the Russian practice shows, export growth and SME support programs, which were financed by Vnesheconombank, failed to be sufficiently effective $[14,15]$. Budgetary funding was not enough to 
decrease the effective interest rate on loans down to the expected level, and entities within the Vnesheconombank system needed additional capitalization.

Whereas fiscal revenue from oil and gas (considering circumstances impeding the recovery of global oil prices to the former level of 2014), fiscal deficit and reduction in sovereign funds, the Russian government cannot provide the same State aid to Russian economic growth and export projects as it used to. The Western sanctions obstruct access to the global financial market.

It may take much more time for the domestic financial market to reach such a development phase, which would allow it to finance its economic needs in the long run, as compared with the available time to enjoy the existing competitive advantages after the Russian ruble devaluation and reaffirm its results in the EEU integration project.

Therefore, the establishment of the EEU currency union and the use of a new collective unit of account still remains a relevant topic for discussion, though it is not stipulated in the Treaty on the Eurasian Economic Union.

Currently, there are neither economic, nor political premises for the single currency to be introduced. However, as the European experience shows us, it takes quite a long time to form a currency union, with a good start often paving the way to the final success. For example, experts share promising ideas concerning the concept of settlements implying that customs duties on import are distributed among the EEU countries.

It is noteworthy that an increase in cashless payments for goods and services may significantly contribute to the development of the integrated payment zone within the EEU in the case of retail operations [16,17] and departure of Armenia and Kazakhstan from the U.S. dollar. In this respect, the countries should undertake measures to make financial services more affordable and increase the financial literacy of their population.

Hence we can make the following conclusions on the current situation in trade settlements among the EEU countries.

1. Russia is the main supplier of resources, including energy, to other participants of the integration process. It also has the largest or one of the most promising markets consuming or manufacturing industrial (agricultural) products, which is not very competitive in other markets. This opens opportunities to involve other participants into the project, with Tajikistan being one of the most obvious candidates.

2. Under all other things being equal, the Russian financial market is lucrative for investors from other EEU countries, in terms of its capacity, liquidity, business volume and sustainability of institutions (intermediaries), development of trading and post-trade facilities, supervisory and regulatory apparatus. The EEU countries should make additional efforts, including regulatory and legislative ones, to make their financial markets equally attractive for they are not homogeneous in terms of their development level.

3. The EEU countries have liberal currency laws. The specifics of the Belarus laws does not obstruct the settlements in currencies, other than freely circulating ones. According to the community of experts, there are not legislative impediments for the countries to use their national currencies for invoicing purposes. The issues will be ultimately resolved after the countries sign a document on concerted approaches to regulating currency transactions and undertaking liberalization measures. April 14, 2017, the RF Government released Instruction of the RF Government № 697-p to do so. 


\section{Figure 1}

The use of the currencies in global payments and trade, 2014

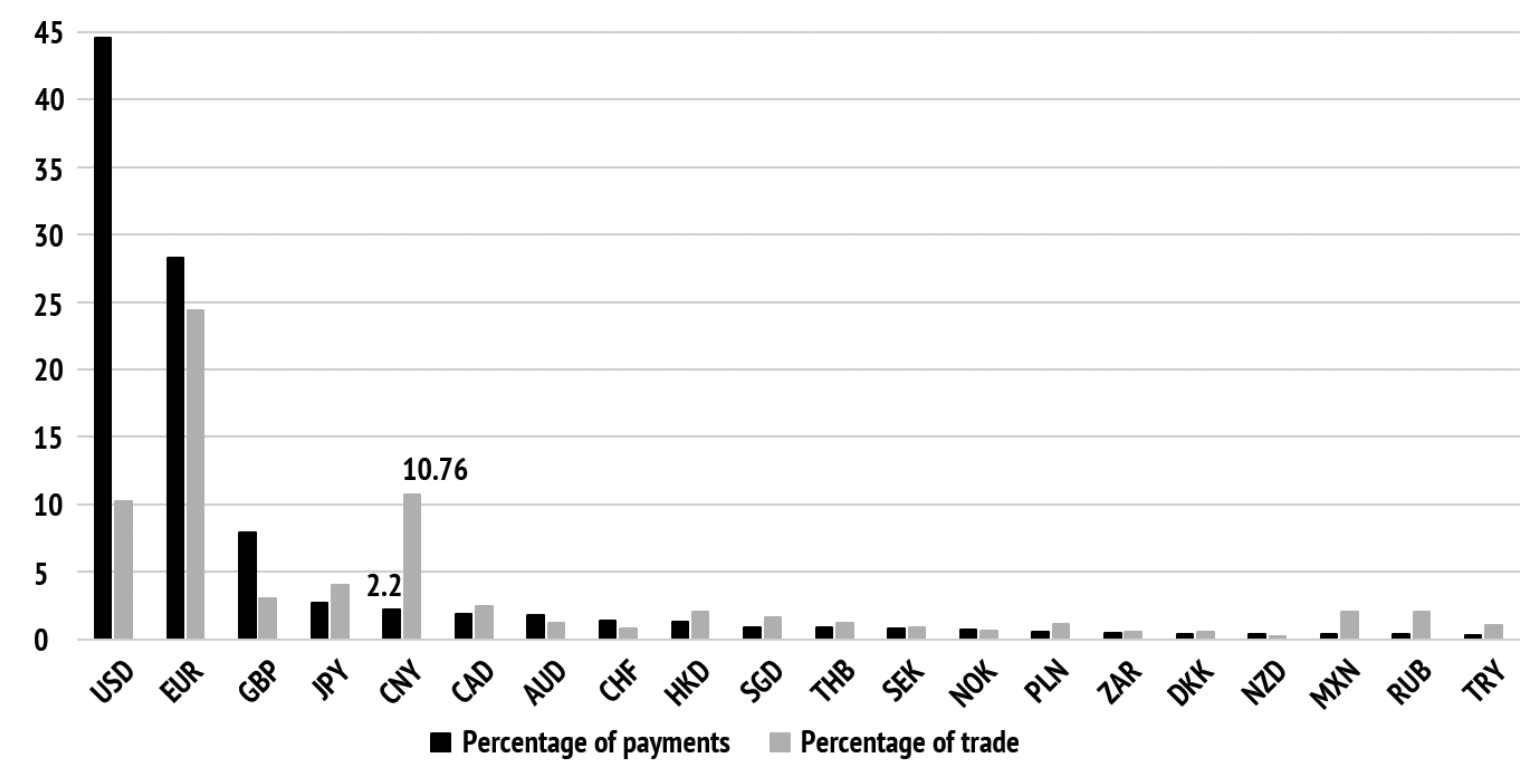

Source:SWIFT, The International Monetary Fund data 


\section{Figure 2}

The operational model of cross-border transfers from Hong Kong to mainland China

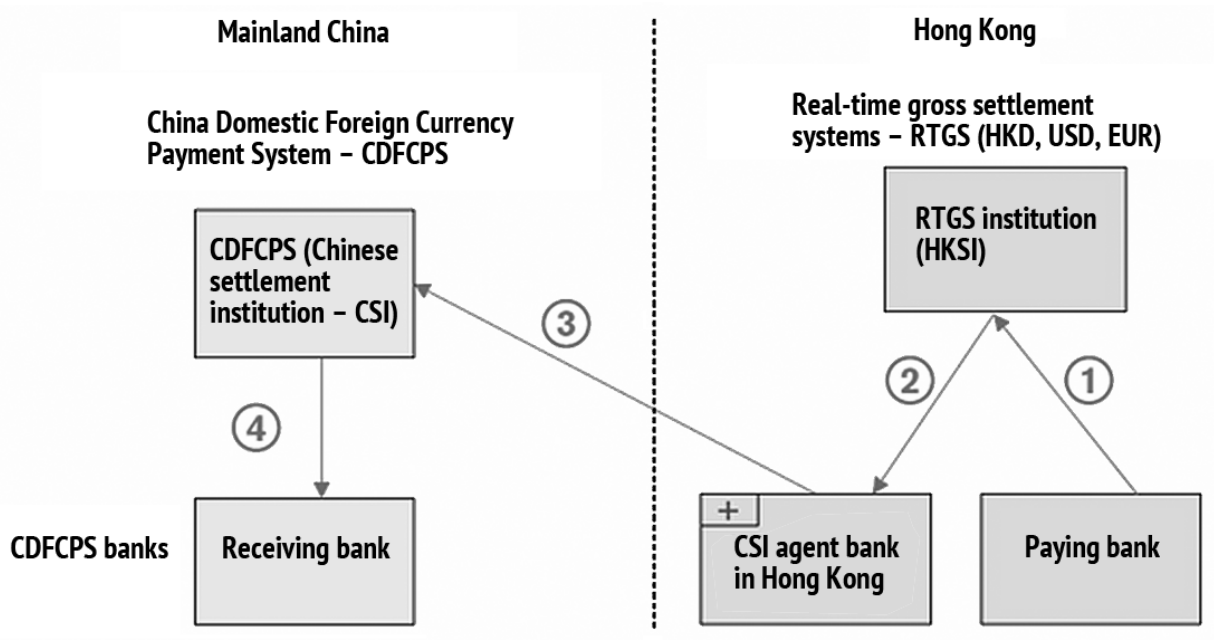

Note. 1 stands for a paying bank in Hong Kong sends a payment order via RTGS and wires money to the receiving bank on the continent through an intermediary bank in a respective currency in Hong Kong; 2 refers to the case when an intermediary bank in Hong Kong receives money through the RTGS system; 3 refers to the case when an intermediary bank in Hong Kong credits CSI account held with it and notifies CSI on payment details; 4 refers to the case when CSI transfers a loan to the receiving bank through CDFCPS. Plus is for CSI's account in a respective intermediary bank in Hong Kong.

Source: Multi-currency cross-border payment arrangements between Hong Kong and Mainland China. Feature Article by HKMA Financial Infrastructure Department. Hong Kong Monetary Authority Quarterly Bulletin, June 2009

\section{Figure 3}

The mix of currencies flowing into Russia as part of trade in goods and services, 2016, percentage

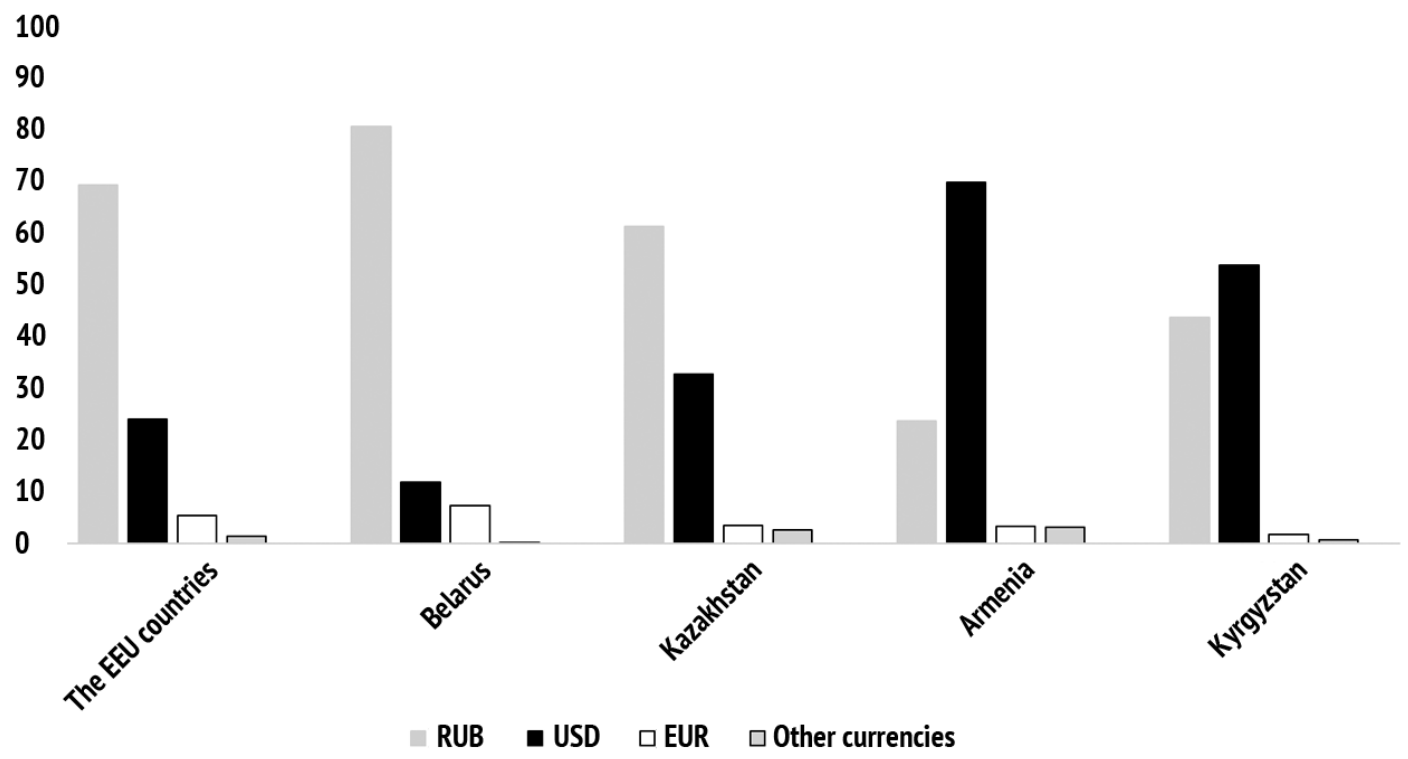

Source:The Central Bank of Russia data

Please cite this article as: Shvandar K.V., Anisimova A.A., Yakovleva I.I. The Future of Monetary Integration in the EEU. Digest Finance, 2018, vol. 23, iss. 3, pp. 297-307. https://doi.org/10.24891/df.23.3.297 


\section{Figure 4}

The mix of currency flowing from Russia as part of trade in goods and services, 2016, percentage

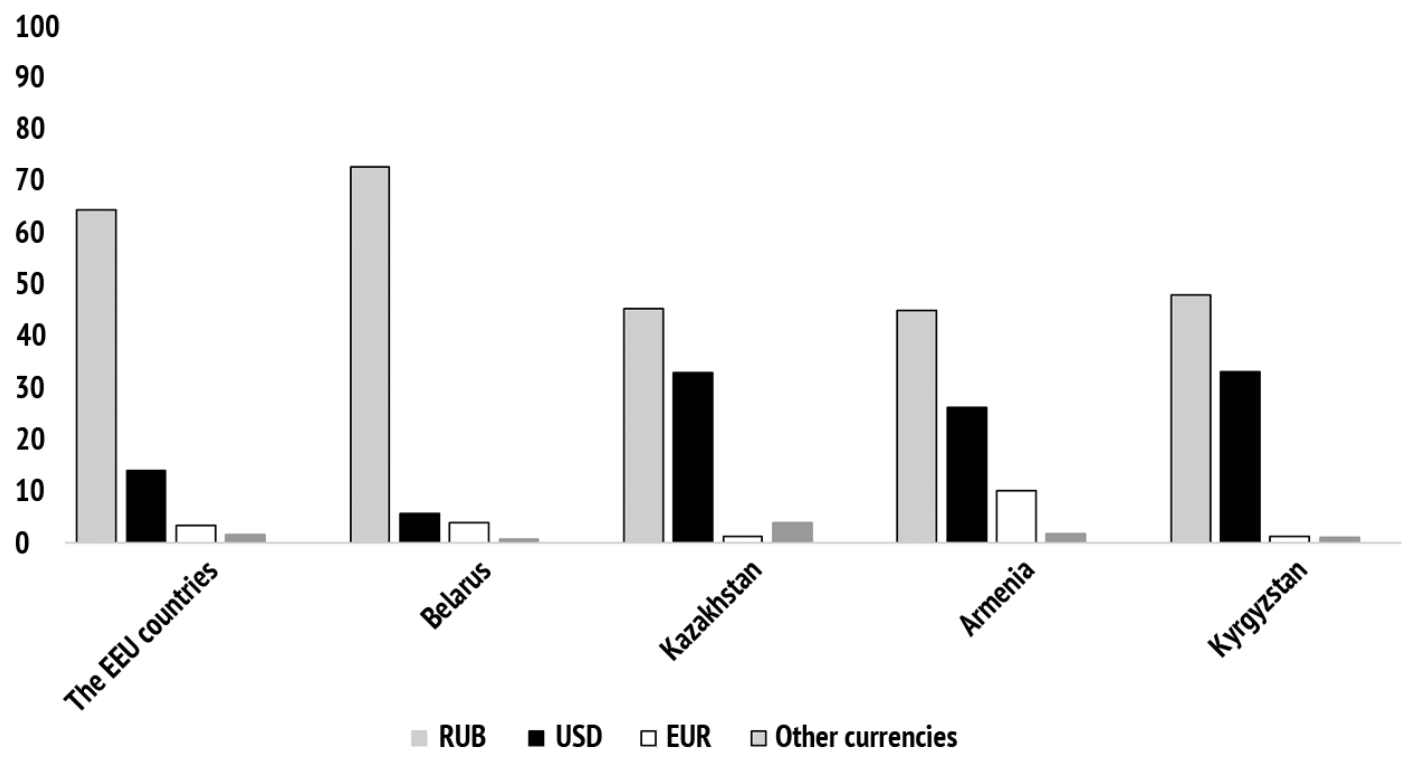

Source:The Central Bank of Russia data

\section{Figure 5}

Foreign trade of Russia with the EEU countries in 2016, billion USD

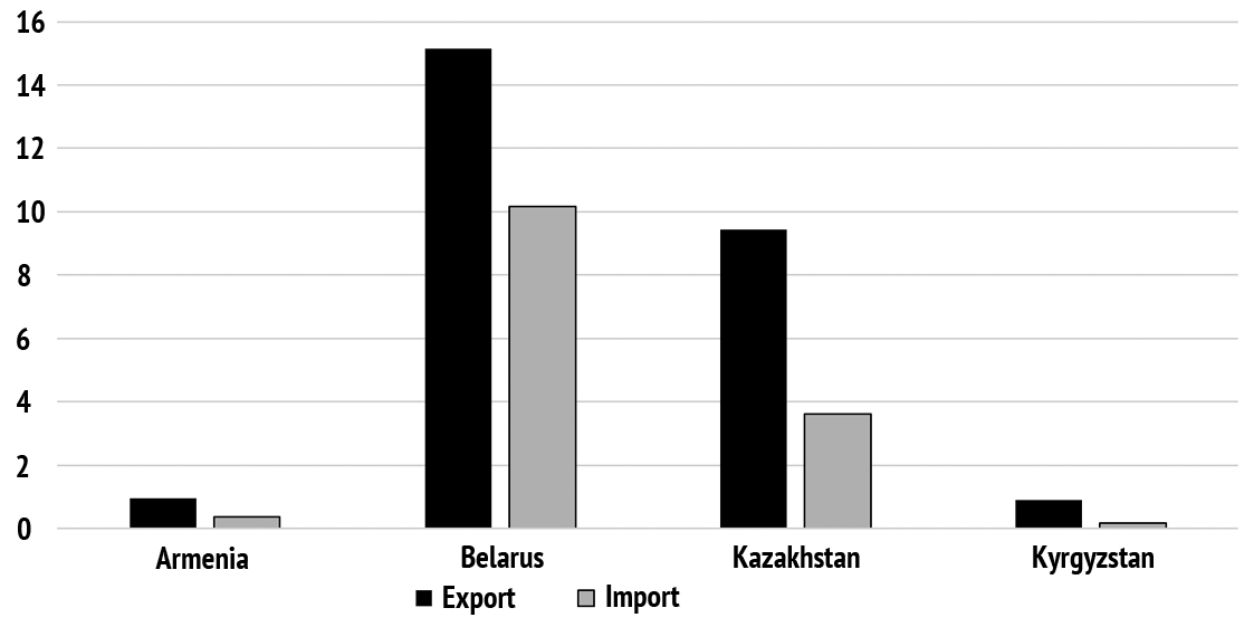

Source:The Federal Customs Service of Russia data 


\section{References}

1. Cheng E., Wang C. The Possibility of Creating a Global Currency, and the Path to Its Realization. World Review of Political Economy, 2011, vol. 2, iss. 4, pp. 543-561.

2. Endres A.M. Currency Competition: A Hayekian Perspective on International Monetary Integration. Journal of Money, Credit and Banking, 2009, September, vol. 41, iss. 6, pp. 1251-1263. URL: https://ideas.repec.org/a/mcb/jmoncb/v41y2009i6p1251-1263.html

3. Faudot A., Ponsot J.-F. The Dollar Dominance: Recent Episode of Trade Invoicing and Debt Issuance. Journal of Economic Integration, 2016, March, vol. 31, iss. 1, pp. 41-64. URL: https://doi.org/10.11130/jei.2016.31.1.41

4. Frankel J.A. Internationalization of the RMB and Historical Precedents. Journal of Economic Integration, 2012, September, vol. 27, iss. 3, pp. 329-365. URL: https://doi.org/10.2307/23317238

5. Leung M.K. Hong Kong and the Internationalisation of the RMB. China Perspectives, 2011, July, no. 3, pp. 67-77.

6. Mallaby S., Wethington O. The Future of the Yuan: China's Struggle to Internationalize Its Currency. Foreign Affairs, 2012, January/February, vol. 91, iss. 1, pp. 135-146. URL: https://www.foreignaffairs.com/articles/china/2011-12-15/future-yuan

7. Glazunov A.V., Shvandar K.V., Anisimova A.A. [Development of national payment systems as the current trend]. Nauchno-issledovatel'skii finansovyi institut. Finansovyi zhurnal = Financial Research Institute. Financial Journal, 2016, no. 5, pp. 94-102. URL: http://www.nifi.ru/images/FILES/Journal/Archive/2016/5/fm_2016_5.pdf (In Russ.)

8. Mishina V.Yu., Dranishnikova M.V. [Russian ruble in Eurasian integration: new challenges and opportunities]. Bankovskoe delo, 2016, no. 2, pp. 36-44. (In Russ.)

9. Suvorov G.I. [On monetary and financial integration in the framework of the Eurasian Economic Union]. Den'gi i kredit = Money and Credit, 2015, no. 6, pp. 3-5. URL: http://www.cbr.ru/Content/Document/File/26610/suvorov_06_15.pdf (In Russ.)

10. Tavadyan A.A. [Key aspects in coordination of the money-and-credit politics in EEC countries in the context of crisis processes (Armenia, Erevan)]. Problemy sovremennoi ekonomiki $=$ Problems of Modern Economics, 2015, no. 4, pp. 34-36. URL: http://www.m-economy.ru/art.php?nArtld=5583 (In Russ.)

11. Shvandar K.V. [World crisis through the prism of pay balance and competitiveness]. Bankovskoe delo, 2009, no. 5, pp. 54-60. (In Russ.)

12. Shvandar K.V., Plotnikov S.V., Borodin A.D. [Modelling scope for forecasting the situation on the world oil markets]. Den'gi $i$ kredit = Money and Credit, 2010, no. 4, pp. 63-69. (In Russ.)

13. Shvandar K.V., Anisimova A.A. [Foreign experience of development of cashless payment system: practice and results]. Nauchno-issledovatel'skii finansovyi institut. Finansovyi zhurnal = Financial Research Institute. Financial Journal, 2015, no. 1, pp. 91-98. URL: http://www.nifi.ru/images/FILES/Journal/Archive/2015/1/123\%20January-February\%202015.pdf (In Russ.)

14. Shvandar K.V., Anisimova A.A. Ogranichenie nalichnykh denezhnykh raschetov kak variant stimulirovaniya razvitiya beznalichnykh platezhei v ekonomike: zarubezhnyi opyt [Cash payments restriction as a way of development incentive of non-cash payments in the economy: world experience]. Moscow, MAKS Press Publ., 2016, 80 p. 
15. Shvandar K.V., Anisimova A.A. [Limitation of cash payments as a method of non-cash payment development in different countries]. Bankovskoe delo, 2015, no. 1, pp. 25-30. (In Russ.)

16. Shvandar K.V., Anisimova A.A. Mezhdunarodnaya konkurentosposobnost': sovremennyi vzglyad na kontseptsiyu [International competitiveness: A modern view at the concept]. Moscow, MAKS Press Publ., 2006, 48 p.

17. Shvandar K.V. Mezhdunarodnaya konkurentosposobnost stran-eksporterov nefti [International competitiveness of the petroleum exporting countries]. Moscow, MAKS Press Publ., 2009.

\section{Conflict-of-interest notification}

We, the authors of this article, bindingly and explicitly declare of the partial and total lack of actual or potential conflict of interest with any other third party whatsoever, which may arise as a result of the publication of this article. This statement relates to the study, data collection and interpretation, writing and preparation of the article, and the decision to submit the manuscript for publication. 